\author{
A. Prabhu $\bowtie$ \\ M. Venkata Ramanan \\ Harish Venu \\ J. Jayaprabakar \\ M. Anish \\ Nivin Joy
}

https://doi.org/10.21278/TOF.453012919

ISSN 1333-1124

eISSN 1849-1391

\title{
EMISSION AND PERFORMANCE CHARACTERISTICS OF A DIESEL ENGINE USING COPPER OXIDE NANOPARTICLES IN PALM OIL BIODIESEL-DIESEL BLENDS
}

\begin{abstract}
Summary
In the present experimental study, the influence of copper oxide $(\mathrm{CuO})$ nanoparticles on emissions and performance of a $4.4 \mathrm{~kW}$ diesel engine powered by palm oil biodiesel have been analyzed. Palm oil biodiesel of $20 \%$ by volume was blended with diesel fuel and the resulting blend is termed as $\mathrm{B} 20$. The B20 test fuel blends were doped with $\mathrm{CuO}$ nanoparticles with concentrations of $25 \mathrm{ppm}, 50 \mathrm{ppm}$, and $75 \mathrm{ppm}$. Experiments were carried out at $0 \%, 25 \%, 50 \%, 75 \%$, and $100 \%$ engine loads at a constant speed $(1,500 \mathrm{rpm})$. Performance parameters such as brake thermal efficiency (BTE) and brake specific energy consumption (BSEC), emission parameters such as carbon monoxide (CO), carbon dioxide (CO2), hydrocarbons (HC), nitrogen oxides (NOx), and smoke opacity were analysed. It was observed that when $\mathrm{CuO}$ nanoparticles were used as additives for the $\mathrm{B} 20$ blend, BTE increased significantly by about $1.18 \%-7.69 \%$ and BSEC decreased considerably by about $4.12 \%-6.76 \%$. In addition, when $\mathrm{CuO}$ nanoparticles were added, there were also substantial reductions in CO $(2.21 \%-8.86 \%)$. Furthermore, there was a noticeable increase in HC $(0.3 \%$ - 9.78\%), CO2 (2.38\% - 5.97\%), and NOx emission levels (1.75\% - 5.27\%) when compared to the B20 blend. However, in comparison to diesel fuel, all the emission levels were lower for all biodiesel blends except for NOx emissions. Overall, it was concluded that $\mathrm{CuO}$ nanoparticles could be considered as an appropriate petroleum additive for palm oil biodiesel blends.
\end{abstract}

Key words: $\quad$ biodiesel, copper oxide, nanoparticle, performance, emissions, additive

\section{Introduction}

The use of biodiesel and its blends in diesel engines is increasing rapidly because of the emerging need of replacing fossil fuels as they will be depleted soon. Consumption of conventional fuels causes numerous air pollutants that affect human health and the environment [1-4]. Fossil fuel depletion has brought about an increase in attention directed to sustainable alternative fuels. Biodiesel is considered to be a better alternative fuel that can be 
used in diesel engines. Biodiesels are produced from various sources which include plants, algae, animal fat, vegetable oils, waste oil, etc. Biodiesels produced from animal fat and vegetable oil are biodegradable and non-toxic in nature [5-8]. Biodiesel can be formulated by the reaction between alcohol and triglyceride with an aid of a catalyst $[9,10]$. The properties and chemical compositions of biodiesel are almost similar to those of petroleum fuels. Conversely, biodiesels do not have sulfur, polycyclic aromatics and harmful compounds [11]. The recent literature on biodiesel fuelled diesel engines shows that such diesel engines can reduce the presence of various emissions, including $\mathrm{CO}_{2}, \mathrm{CO}, \mathrm{HC}$, and smoke emissions although there is an increase in $\mathrm{NO}_{\mathrm{x}}$ emissions [12-15]. Biodiesel fuel properties play a major role in exhaust emissions from diesel engines. Different nanoadditives have been adopted in biodiesel preparation to improve fuel blend quality in addition to enhancing the combustion processes and thereby reducing engine exhaust emissions [16, 17]. Nanoparticles are additives added to biodiesel fuel blends which act as potential catalysts thereby reducing the emissions. The inclusion of nanoparticles to biodiesel fuel blends can improve their properties (kinematic viscosity, flash point, cloud point, and pour point etc.) owing to their high surface area-tovolume ratio, mass diffusivity and thermal conductivity [18, 19]. Metal oxides including aluminium oxide, copper oxide, titanium oxide, iron oxide etc. are frequently used as nanoparticles. Furthermore, some polymeric, carbon and ceramic nanoparticles were also used in biodiesel preparation to improve fuel properties [20-21].

Several experimental investigations have been made on the influence of nanoparticles on emission and performance characteristics of a diesel engine fuelled by diesel-biodiesel blends. Hosseini et al. [22] examined the effect of nanoparticles of aluminium oxide (alumina) on waste cooking oil biodiesel-diesel blends used to fuel a single cylinder direct injection diesel engine. Alumina nanoparticle proportions of $30 \mathrm{ppm}, 60 \mathrm{ppm}$, and $90 \mathrm{ppm}$ were used, while the engine operated at various engine speeds $(1,800 \mathrm{rpm}-3,300 \mathrm{rpm})$. The authors observed that the blend $\mathrm{B} 10+90 \mathrm{ppm}$ showed an increase in BTE, exhaust gas temperature (EGT), and brake power (BP) of about $10.63 \%, 5.36 \%$, and $5.8 \%$, respectively, and a decrease in brake specific energy consumption (BSEC) by about $14.52 \%$ when compared to neat diesel.

Prabu and Anand [23] experimentally studied engine parameters of a diesel engine powered by Jatropha biodiesel doped with ceria oxide and aluminium oxide nanoadditive. Both additives are mixed with equal proportions of $10 \mathrm{ppm}$ to $60 \mathrm{ppm}$. The authors observed that $60 \mathrm{ppm}$ doped Jatropha biodiesel blend showed a reduced brake specific fuel consumption (BSFC) and higher BTE owing to the higher surface area-to-volume ratio of nanoadditives that improved the combustion rate significantly. Sivakumar et al. [24] evaluated the impact of aluminium oxide nanoparticles (50 ppm and $100 \mathrm{ppm}$ ) in Pongamia biodiesel $(25 \%)+$ diesel $(75 \%)$ blend (B25) used to fuel a direct injection diesel engine. Their experiments revealed that the B25 +100 ppm fuel blend showed the BSFC lower by about $16.87 \%$ and BTE higher by $9.26 \%$. This is a result of the collective effect of higher flame temperatures, better rate of evaporation, ignition delay, and extended existence of flame.

Ganesh et al. [25] studied the combined effect of the cobalt oxide and magnalium nanoadditives doped Jatropha biodiesel used to fuel a direct injection diesel engine. They found that BTE was lower, and BSFC was increased due to the lower calorific value of Jatropha biodiesel. Also, by adding cobalt oxide and magnesium nanoparticles there was an $1 \%$ rise in BTE when compared to other blends that had no additives. Mehta et al. [26] evaluated the impact of boron, iron, and aluminium nanoadditives on characteristics of a direct injection diesel engine. They found that BSFC decreased by about $6.9 \%$ when compared with neat diesel fuel. Hosseini et al. [27] experimentally investigated the impact of carbon nanotubes on exhaust emission and performance parameters of a single-cylinder diesel engine. They observed that emission levels of $\mathrm{CO}, \mathrm{HC}$ and smoke were considerably reduced 
Emission and Performance Characteristics of a Diesel Engine Using Copper Oxide Nanoparticles in Palm Oil Biodiesel-Diesel Blends
A. Prabhu, M. Venkata Ramanan, Harish Venu, J. Jayaprabakar, M. Anish, Nivin Joy

when carbon nanotube was added. Moreover, it is also observed that BTE, BP, and EGT also improved significantly.

Overall, many researchers anticipated that adding nanoparticles to a biodiesel fuel blend significantly reduced harmful emissions and improved the performance of a diesel engine [2025]. From previous experimental studies, it can be observed that very few studies have been carried out on characteristics of diesel engines fuelled by palm oil biodiesel blends, $\mathrm{CuO}$ nanoparticles (on $25 \mathrm{ppm}$ and $50 \mathrm{ppm}$ concentration) and diesel fuel. In the present study, based on this strategic concept, the following blends were used in the experiments: D100 (neat diesel), B20 (20\% palm oil biodiesel $+80 \%$ diesel), B20N25 (20\% palm oil biodiesel + $80 \%$ diesel +25 ppm CuO nanoparticles), B20N50 (20\% palm oil biodiesel $+80 \%$ diesel + 50 ppm CuO nanoparticles) and B20N75 (20\% palm oil biodiesel $+80 \%$ diesel +75 ppm $\mathrm{CuO}$ nanoparticles).

\section{Materials and methods}

\subsection{Preparation of copper oxide nanoparticle biodiesel blends}

$\mathrm{CuO}$ nanoparticles were preferred as the fuel additive because of their improved physical and chemical properties, such as thermal heat conductivity, high heat capacity, low thermal expansion and high melting temperature when compared to other nanoparticles. Additionally, $\mathrm{CuO}$ particles are considered as non-toxic and more environmentally friendly than other metal-based nanoparticles [28]. Further, it is also found that adding $\mathrm{CuO}$ nanoparticles increases the auto-ignition temperature of fuel blends [29]. Various properties of $\mathrm{CuO}$ nanoparticles are given in Table 1 . Palm oil was produced by transesterification to be suitable for use in diesel engines as given in Fig. 1. CuO nanoadditives were characterized by using transmission electron microscope (TEM) and scanning electron microscope (SEM) images and their details are given in Fig. 2.

$\mathrm{CuO}$ nanoparticles were mixed with palm oil biodiesel-diesel blend (B20) in the quantities of $25 \mathrm{ppm}, 50 \mathrm{ppm}$, and $75 \mathrm{ppm}$ by an ultrasonicator (R-4C model). In order to evaluate the stability of the nanoparticles dispersed in the palm oil biodiesel-diesel blend, the blends were checked for stability and homogeneity for 15 days, and the samples showed the minimum separation of nanoparticles [30]. The physical and chemical properties of $\mathrm{CuO}$ nanoparticles doped palm oil biodiesel-diesel blends are given in Table 2.

Table 1 Properties of $\mathrm{CuO}$ nanoparticles

\begin{tabular}{ll}
\hline Item & Nanoparticle sample \\
\hline Composition & copper $80 \%$, oxygen $20 \%$ \\
Colour & black \\
Form & powder \\
Molecular weight & $32.85 \mathrm{~g} / \mathrm{mol}$ \\
Average size of particle & $10-20 \mathrm{~nm}$ \\
Molar mass & $79.5 \mathrm{~g} / \mathrm{mol}$ \\
Boiling point & $2,000^{\circ} \mathrm{C}$ \\
Melting point & $1,201{ }^{\circ} \mathrm{C}$ \\
Density & $6.31 \mathrm{~g} / \mathrm{cm}^{3}$ \\
Thermal conductivity & $0.732 \mathrm{~W} / \mathrm{mK}$ \\
\hline
\end{tabular}


A. Prabhu, M. Venkata Ramanan, Harish Venu, J. Jayaprabakar, M. Anish, Nivin Joy
Emission and Performance Characteristics of a Diesel Engine Using Copper Oxide Nanoparticles in Palm Oil Biodiesel-Diesel Blends

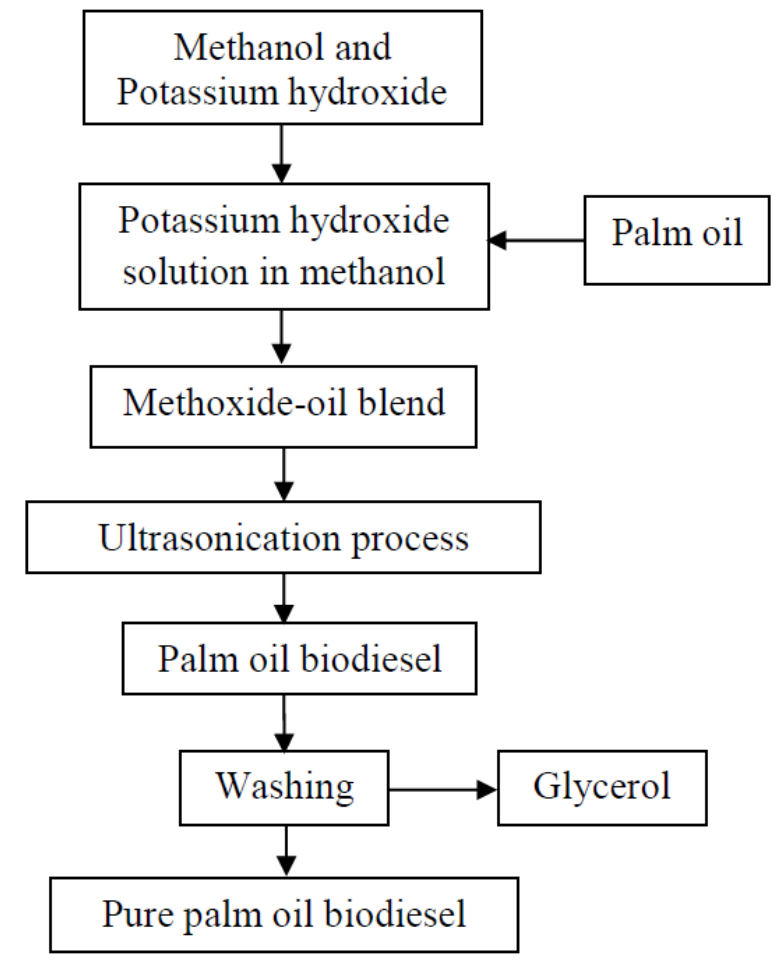

Fig. 1 The process of palm oil biodiesel production
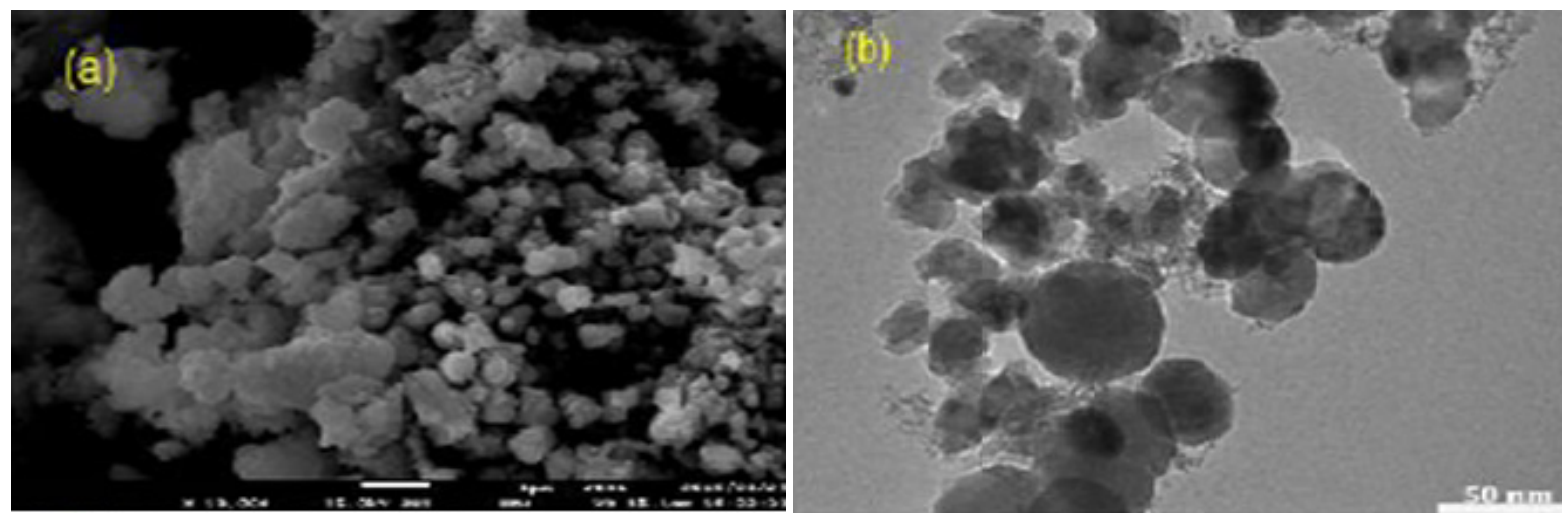

Fig. 2 (a) TEM \& (b) SEM images of $\mathrm{CuO}$ nanoparticles

Table 2 Properties of test blends

\begin{tabular}{lllllll}
\hline Properties & D100 & B20 & B20N25 & B20N50 & B20N75 & $\begin{array}{l}\text { ASTM } \\
\text { standard }\end{array}$ \\
\hline $\begin{array}{l}\text { Kinematic viscosity at } \\
40{ }^{\circ} \mathrm{C}(\mathrm{cSt})\end{array}$ & 2.98 & 3.29 & 3.18 & 3.14 & 3.21 & D445 \\
$\begin{array}{l}\text { Density at } 20{ }^{\circ} \mathrm{C}\left(\mathrm{kg} / \mathrm{m}^{3}\right) \\
\text { Calorific value }(\mathrm{kJ} / \mathrm{kg})\end{array}$ & 832 & 862 & 847 & 845 & 841 & D1298 \\
Cetane number & 47 & 49.7 & 50.4 & 50.9 & 50.3 & D976 \\
Flash point $\left({ }^{\circ} \mathrm{C}\right)$ & 67 & 58 & 59 & 62 & 61 & D93 \\
\hline
\end{tabular}


Emission and Performance Characteristics of a Diesel Engine Using Copper Oxide Nanoparticles in Palm Oil Biodiesel-Diesel Blends
A. Prabhu, M. Venkata Ramanan, Harish Venu, J. Jayaprabakar, M. Anish, Nivin Joy

\subsection{Experimental set-up and testing procedure}

A single-cylinder diesel engine (Kirloskar) with dynamometer (eddy current) loading arrangement was used in the experiments. The experiments were carried out for the engine loads from $0 \%$ to $100 \%$ with increments of $25 \%$. The layout of the experimental engine setup is presented in Fig. 3. The technical specifications of the engine are presented in Table 3. An exhaust gas analyzer (model $\mathrm{QRO} / 402$ ) was used for measuring $\mathrm{CO}, \mathrm{CO}_{2}, \mathrm{HC}$, and $\mathrm{NO}_{\mathrm{x}}$ emission levels. A smoke meter (model AVL437C) was employed for measuring the smoke opacity. Table 4 displays uncertainties of instruments and measurement accuracies obtained from the calculated results.

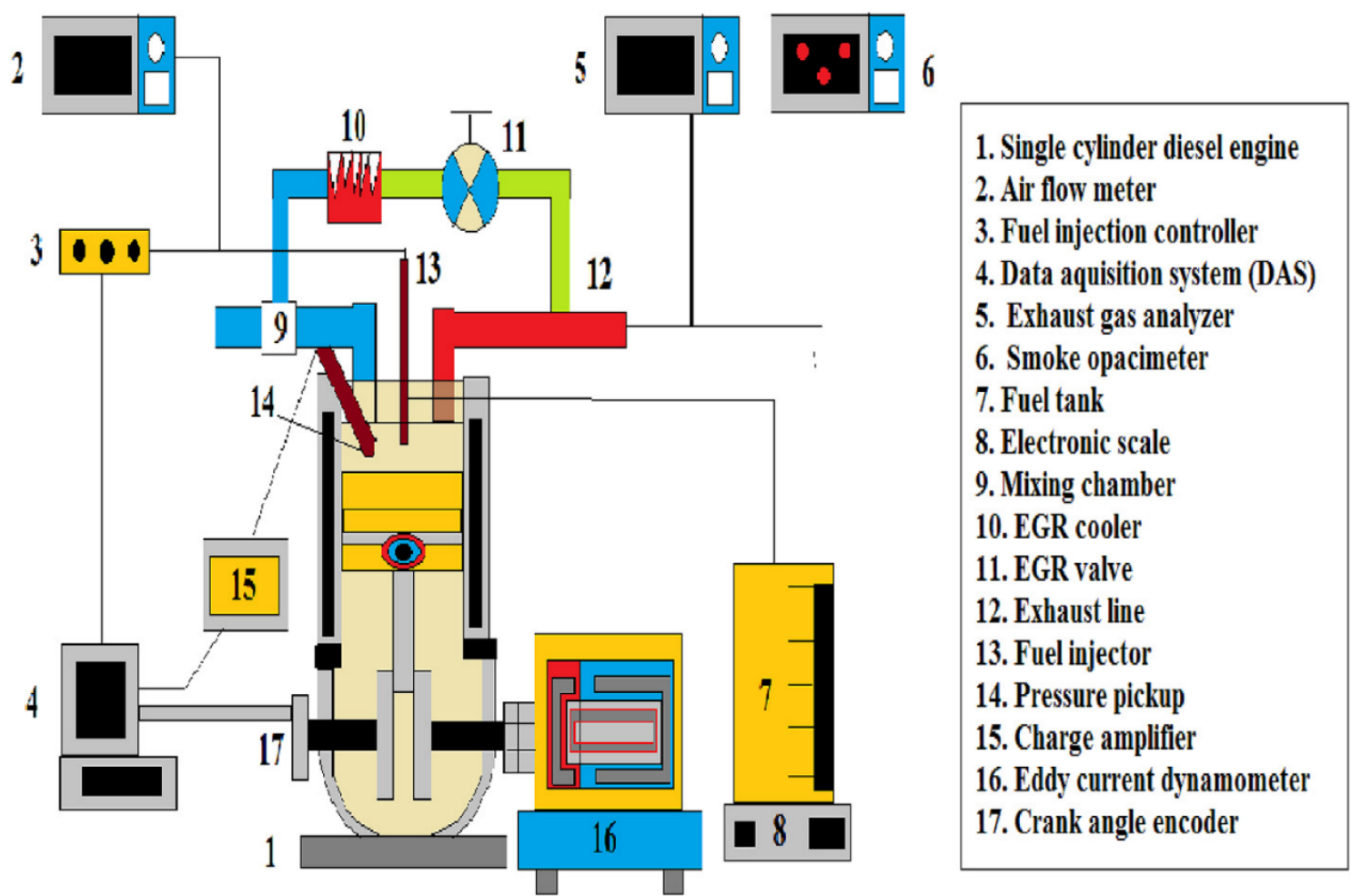

Fig. 3 Experimental engine set-up

Table 3 Technical specifications of the engine

\begin{tabular}{ll}
\hline Make & Kirloskar \\
No. of cylinder & single cylinder \\
Type & four stroke, direct injection diesel engine \\
Rated power & $4.4 \mathrm{~kW}$ \\
Rated speed & $1,500 \mathrm{rpm}$ \\
Engine capacity & $661 \mathrm{~cm}^{3}$ \\
Bore \& stroke & $87.5 \mathrm{~mm}, 110 \mathrm{~mm}$ \\
Compression ratio & $17.5: 1$ \\
Normal injection pressure & $200 \mathrm{bar}$ \\
Normal injection timing & $23^{\circ} \mathrm{bTDC}$ \\
\hline
\end{tabular}


A. Prabhu, M. Venkata Ramanan, Harish Venu,

J. Jayaprabakar, M. Anish, Nivin Joy
Emission and Performance Characteristics of a Diesel Engine Using Copper Oxide Nanoparticles in Palm Oil Biodiesel-Diesel Blends

Table 4 Uncertainties of instruments

\begin{tabular}{lcccc}
\hline \multicolumn{1}{c}{ Device } & $\begin{array}{c}\text { Measured } \\
\text { quantity }\end{array}$ & Range & Accuracy & $\begin{array}{c}\text { Uncertainties } \\
(\%)\end{array}$ \\
\hline Gas analyzer & $\mathrm{CO}$ & $0-9.99 \% \mathrm{vol}$. & $\pm 0.02 \%$ & \pm 0.2 \\
(AVL 444 Di-Gas) & $\mathrm{CO}_{2}$ & $0-19.99 \% \mathrm{vol}$. & $\pm 0.03 \%$ & \pm 0.2 \\
& $\mathrm{HC}$ & $0-15,000 \mathrm{ppm}$ & $\pm 50 \mathrm{ppm}$ & \pm 0.3 \\
& $\mathrm{NO}_{\mathrm{x}}$ & $0-5,000 \mathrm{ppm}$ & $\pm 10 \mathrm{ppm}$ & \pm 0.2 \\
Smoke meter (AVL 437C) & smoke opacity & $0-100 \mathrm{HSU}$ & $\pm 0.1 \mathrm{HSU}$ & \pm 1.0 \\
Burette & fuel & $1-100 \mathrm{~cm}^{3}$ & $\pm 0.1 \mathrm{~cm}^{3}$ & \pm 1.0 \\
Digital tachometer & engine speed & $0-10,000 \mathrm{rpm}^{2}$ & $\pm 10 \mathrm{rpm}$ & \pm 0.1 \\
Eddy current dynamometer & engine load & $200-8,000 \mathrm{~W}$ & $15 \mathrm{~W}$ & \pm 0.3 \\
Pressure transducer & pressure & $0-100 \mathrm{bar}$ & $\pm 0.1 \mathrm{bar}$ & \pm 0.1 \\
\hline
\end{tabular}

The data acquisition system (DAS) was connected from the diesel engine to the computer and it stored the in-cylinder pressure and its associated data for further calculation. Then, a combustion analyser kit was installed on the diesel engine to analyse the ignition delay period, the start of combustion, the heat release rate, the mass fraction burnt and the combustion duration inside the cylinder. An optical sensor was fitted near to the flywheel to ensure a constant speed of the diesel engine (maximum of 1,500 rpm). Meanwhile, tailpipe emissions were analysed by using a five gas analyser AVL444 in the conditions of steady state engine operation.

Then, this filtered gas was allowed to reach a nondispersive infrared sensor for $\mathrm{HC}, \mathrm{CO}$ and $\mathrm{CO}_{2}$ emissions and oxides of nitrogen $\left(\mathrm{NO}_{\mathrm{x}}\right)$ to be measured using an electrochemical sensor. After the measurement, a smoke emission analysis carried out by an AVL $437 \mathrm{C}$ type smoke meter was done. This engine test was conducted at $0 \%, 25 \%, 50 \%, 75 \%$ and $100 \%$ brake load conditions. Then, between the uses of other fuel blends, the engine was run by pure diesel fuel to ensure better combustion and homogeneity in the cylinder.

\subsection{BTE and BSEC calculation}

The instrument used to measure the output power is dynamometer, which has a stationary rotor bounded by electromagnets and coupled with a crankshaft by flexible coupling. The rotor's rotary motion acts against the magnetic field generated by the electromagnet when supplied with sufficient electric current. This in turn creates resistance to rotor and thereby load is applied to the engine. Hence, varying the current supplied to the electromagnet can alter the load. The opposing force created on the dynamometer is measured by the change in the strain gauge, based on which torque is measured by multiplying the Rdistance between the centre of the pivotal point (strain gauge) and the varied opposing force.

$$
T=F \cdot R
$$

Based on the obtained torque, the brake power (BP) output can be evaluated for the test engine which operates at a constant speed of 1,500 rpm as follows:

$$
\mathrm{BP}=\frac{2 \pi \cdot N \cdot T}{60} \cdot S(\mathrm{~kW})
$$

where, BP denotes brake power, $N$ denotes constant engine speed (here 1,500 rpm), $T$ denotes the torque generated and $S$ denotes the dynamometer constant. From the above equation, the 
Emission and Performance Characteristics of a Diesel Engine Using Copper Oxide Nanoparticles in Palm Oil Biodiesel-Diesel Blends
A. Prabhu, M. Venkata Ramanan, Harish Venu, J. Jayaprabakar, M. Anish, Nivin Joy

respective brake powers generated by the engine at engine loads of $0 \%, 25 \%, 50 \%, 75 \%$ and $100 \%$ at the speed of $1,500 \mathrm{rpm}$ can be evaluated. The total fuel consumed by the engine is evaluated by the consumption of certain quantity of fuel $\left(10 \mathrm{~cm}^{3}\right)$ at varying time period with the help of a stopwatch. With the load increasing, more fuel is injected to maintain the engine speed constant (at 1,500 rpm). Total fuel consumption (TFC) can be calculated by the following formula:

$$
\mathrm{TFC}=\frac{\rho \cdot v}{t}(\mathrm{~g} / \mathrm{s})
$$

where, $\rho$ denotes fuel density, $v$ denotes the volume of fixed quantity (here it is $10 \mathrm{~cm}^{3}$ ) and $t$ denotes the time taken by stopwatch during the consumption of $10 \mathrm{~cm}^{3}$ fuel. From BP and TFC, brake specific fuel consumption (BSFC) can be evaluated by the amount of fuel consumed for getting $1 \mathrm{~kW}$ power output. In general, BSFC is preferred when experimental fuels are used which have similar values of density and calorific values. However, brake specific energy consumption (BSEC) is more specific than BSFC as it correlates the varying density and the calorific value of experimental fuels. BSEC is simply the amount of energy supplied (MJ) to an engine operated for one hour and generating $1 \mathrm{~kW}$ power output. It can be calculated by the following formula:

$$
\begin{aligned}
& \mathrm{BSFC}=\frac{\text { energy intake of the engine for one hour }}{\text { brake power gained in the engine crankshaft }} \\
& \mathrm{BSEC}=\frac{\mathrm{TFC} \cdot 3600}{\mathrm{BP}} \cdot \mathrm{CV}(\mathrm{MJ} / \mathrm{kWh})
\end{aligned}
$$

where, BSEC denotes the brake specific energy consumption, BP denotes the brake power developed by the engine and $\mathrm{CV}$ denotes the calorific value of the test fuel subjected to experimentation. Finally, the brake thermal efficiency is determined using the following formula:

$$
\mathrm{BTE}=\frac{\mathrm{BP}}{\mathrm{TFC} \cdot \mathrm{CV}} \cdot 100(\%)
$$

where, BTE denotes the brake thermal efficiency, TFC denotes the total fuel consumption and $\mathrm{CV}$ denotes the calorific value of the test fuel subjected to experimentation.

\section{Results and discussion}

\subsection{Performance characteristics}

The influence of $\mathrm{CuO}$ nanoparticles on the brake thermal efficiency of the diesel engine for D100, B20, B20N25, B20N50, and B20N75 is shown in Fig. 4. It can be seen that the B20 blend exhibits the lowest BTE for all engine loads. This is because of a higher kinematic viscosity and density of biodiesel blends. When compared with neat diesel, the kinematic viscosity of B20 is higher by about $10.4 \%$ which causes the lowest BTE of $28.22 \%$ to occur at $100 \%$ engine load due to incomplete combustion of the B20 blend when compared to neat diesel. The addition of $\mathrm{CuO}$ nanoparticles in $\mathrm{B} 20$ contributes to a substantial improvement in increasing the BTE. It can be observed that the rise in the heating value and decline in the kinematic viscosity with the $\mathrm{CuO}$ nanoparticle doped biodiesel-diesel blend (B20) are the main reasons for the BTE improvement. BTE of the $\mathrm{CuO}$ nanoparticle doped B20 blend was higher by about $2.66 \%, 7.69 \%$, and $1.18 \%$ for B20N25, B20N50, and B20N75 blends, 
respectively, when compared to B20. This could be due to the catalytic activity of nanoparticles which promotes the atomization of fuel droplets [31], further resulting in an increased rate of evaporation and a drop in physical delay leading to an increase in combustion efficiency and higher BTE. Nanoparticles also have a higher surface area-tovolume ratio which could possibly influence the rate of heat transfer inside the engine cylinder [32].

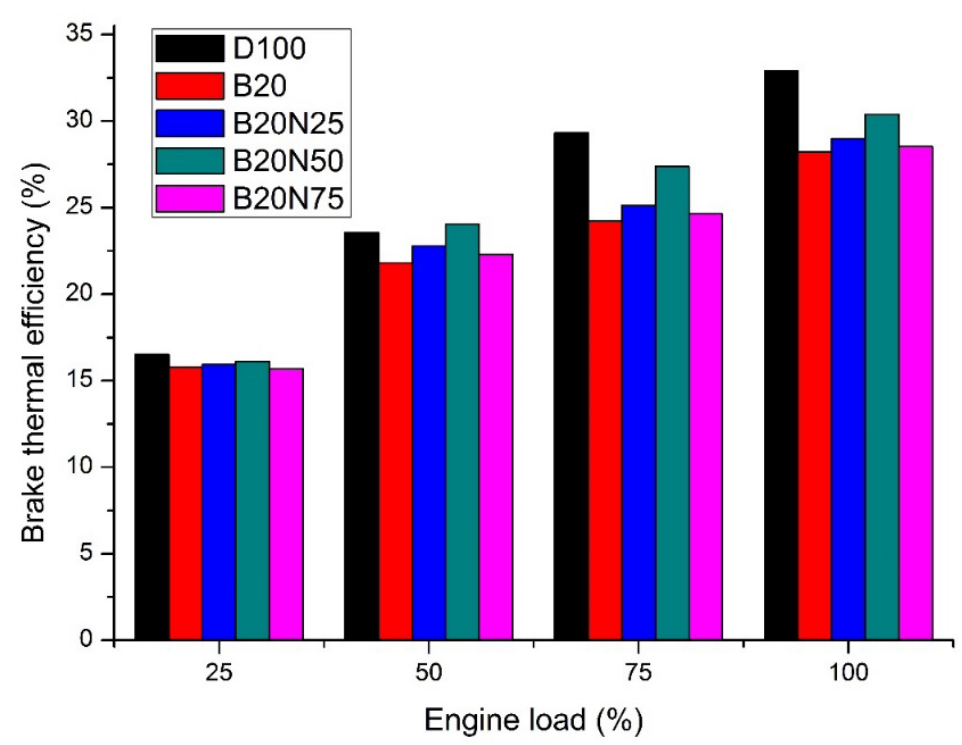

Fig. 4 Brake thermal efficiency for fuel blends versus engine loads

The effects of $\mathrm{CuO}$ nanoparticles on the brake specific energy consumption (BSEC) of the diesel engine for D100, B20, B20N25, B20N50, and B20N75 blends are shown in Fig. 5. It can be observed that B20 displays the maximum energy consumption at all engine loads when compared with diesel (D100) and other test blends. The heating value of the B20 blend is lower than that of neat diesel by about $3.52 \%$ and also the higher kinematic viscosity of B20 lowers the rate of atomization and vaporization of fuel droplets, thus causing a surge in the BSEC profile. The B20 biodiesel-diesel blend displays a downward trend of BSEC due to the presence of oxygen in the blend, promoting combustion. The BSEC of the $\mathrm{CuO}$ nanoparticle doped B20 blend dropped by about 4.17\%, 6.76\%, and 4.12\% for B20N25, $\mathrm{B} 20 \mathrm{~N} 50$, and B20N75 blends, respectively, when compared to the B20 blend. It is found that when $\mathrm{CuO}$ nanoparticles were added, BSEC reduced marginally. This is because of a higher surface area-to-volume ratio of nanoparticles promoting the catalytic activity and improved combustion. Further, there was a decrease in physical delay, an increase in the cetane number which overall lead to BSEC lower than in any other blends. It was also found that the B20N50 blend displayed the lowest BSEC profile at all engine load conditions. Besides, the addition of nanoadditives influences the evaporation rate, ignition delay and spray characteristics, which altogether improves the catalytic activity and improvement in the combustion efficiency subsequently lowering the BSEC profile. Patel and Kumar [33] also found a similar trend of the lower BSEC doped with alumina nanoparticles. 
Emission and Performance Characteristics of a Diesel Engine Using Copper Oxide Nanoparticles in Palm Oil Biodiesel-Diesel Blends
A. Prabhu, M. Venkata Ramanan, Harish Venu, J. Jayaprabakar, M. Anish, Nivin Joy

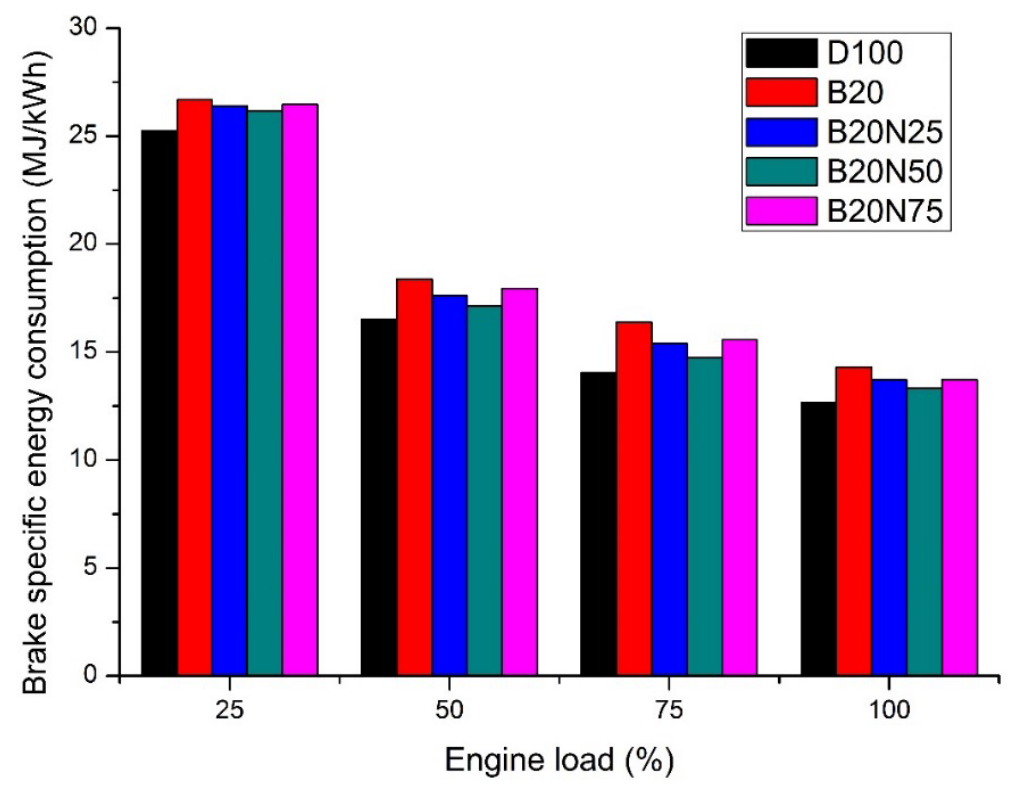

Fig. 5 Brake specific energy consumption for fuel blends versus engine loads

\subsection{Engine emission characteristics}

The influence of $\mathrm{CuO}$ nanoparticles on $\mathrm{CO}$ emissions of the diesel engine for $\mathrm{D} 100$, $\mathrm{B} 20, \mathrm{~B} 20 \mathrm{~N} 25, \mathrm{~B} 20 \mathrm{~N} 50$, and B20N75 blends are shown in Fig. 6. From the figure, an increasing $\mathrm{CO}$ emission trend can be seen with the engine load increasing. It is due to the variation in air-fuel ratio supplied at different engine loads. Furthermore, the B20N75 blend exhibits the lowest $\mathrm{CO}$ emission levels at all engine load conditions. This is because of the high inherent oxygen and high cetane number of $\mathrm{B} 20$ [34]. The $\mathrm{CuO}$ nanoparticle addition in $\mathrm{B} 20$ results in a substantial decrease in $\mathrm{CO}$ emission levels because $\mathrm{CuO}$ nanoparticles promote the oxidation process of converting $\mathrm{CO}$ into $\mathrm{CO}_{2}$. The $\mathrm{CO}$ emission levels of the $\mathrm{CuO}$ nanoparticle doped B20 blend were lower by about $2.21 \%, 6.09 \%$, and $8.86 \%$ for $\mathrm{B} 20 \mathrm{~N} 25, \mathrm{~B} 20 \mathrm{~N} 50$, and B20N75 blends, respectively, when compared to the B20 blend. This is because of the catalytic activity of nanoparticles, which promotes the atomization and evaporation rate resulting in better combustion in the cylinder. Nanoparticles also have a higher surface area-to-volume ratio which could possibly influence the rate of heat transfer [32]. CO emissions could also be reduced owing to a reduced ignition delay causing an increase in the combustion rate [35]. Lower $\mathrm{CO}$ emission levels achieved by adding nanoparticles were reported in different studies [23, 24, 27]. 
A. Prabhu, M. Venkata Ramanan, Harish Venu, J. Jayaprabakar, M. Anish, Nivin Joy
Emission and Performance Characteristics of a Diesel Engine Using Copper Oxide Nanoparticles in Palm Oil Biodiesel-Diesel Blends

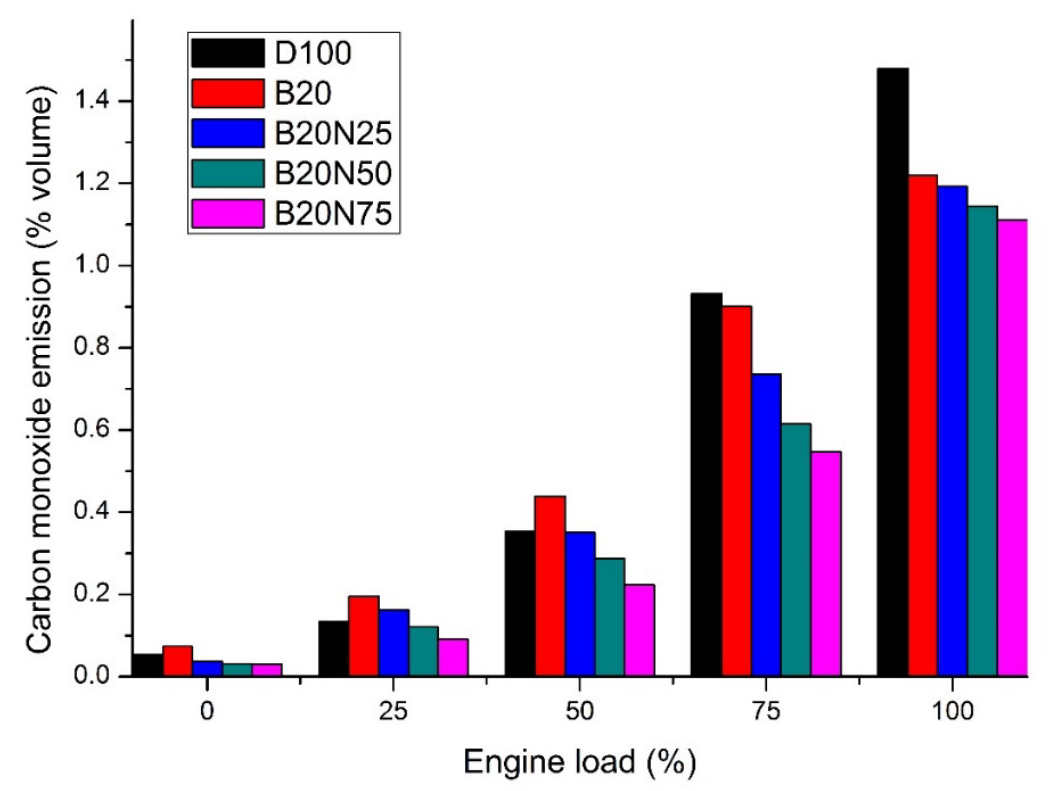

Fig. 6 Carbon monoxide emissions from fuel blends versus engine loads

The influence of $\mathrm{CuO}$ nanoparticles on $\mathrm{CO}_{2}$ emission levels of the diesel engine for D100, B20, B20N25, B20N50, and B20N75 blends are shown in Fig. 7. The $\mathrm{CO}_{2}$ emission levels of the B20 blend are reduced for all engine loads when compared with the $\mathrm{B} 20+\mathrm{CuO}$ nanoparticle blends and this is due to the presence of nanoadditives improving the rate of combustion, followed by a higher oxidation range and higher $\mathrm{CO}_{2}$ liberation as $\mathrm{CO}_{2}$ indicates an improvement in combustion. Adding $\mathrm{CuO}$ nanoparticles to the $\mathrm{B} 20$ blend results in a substantial increase in $\mathrm{CO}_{2}$ emissions because it is evident that there is a trade-off between $\mathrm{CO}$ and $\mathrm{CO}_{2}$.emissions. The nanoparticle addition enhances the combustion process and leads to higher $\mathrm{CO}_{2}$ emissions for the $\mathrm{B} 20+\mathrm{CuO}$ nanoparticle blends since $\mathrm{CuO}$ nanoparticles promote the oxidation process which could convert $\mathrm{CO}$ into $\mathrm{CO}_{2}$ emissions. The $\mathrm{CO}_{2}$ emissions of $\mathrm{CuO}$ nanoparticle doped $\mathrm{B} 20$ blend were increased by about $2.38 \%, 3.76 \%$, and $5.95 \%$ for B20N25, B20N50 and B20N75 blends, respectively, when compared to the B20 blend.

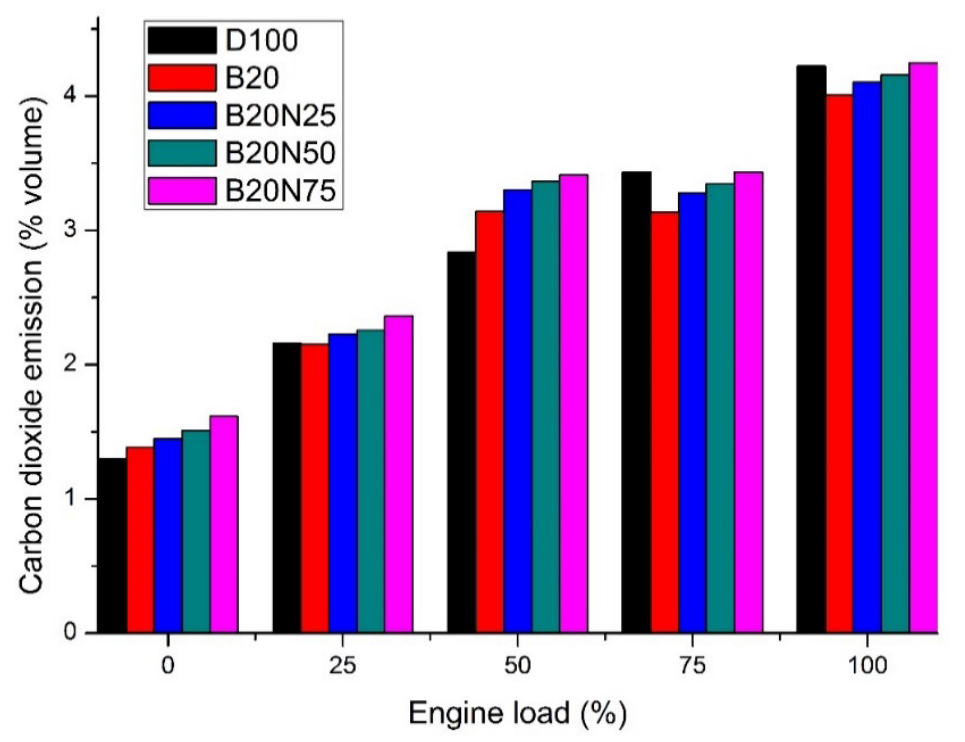

Fig. 7 Carbon dioxide emissions from fuel blends versus engine loads 
Emission and Performance Characteristics of a Diesel Engine Using Copper Oxide Nanoparticles in Palm Oil Biodiesel-Diesel Blends
A. Prabhu, M. Venkata Ramanan, Harish Venu, J. Jayaprabakar, M. Anish, Nivin Joy

The influence of $\mathrm{CuO}$ nanoparticles on $\mathrm{HC}$ emission levels of the diesel engine for D100, B20, B20N25, B20N50, and B20N75 blends is presented in Fig. 8. The emission levels of $\mathrm{HC}$ increase with the engine load increasing due to the leftover fuel in the combustion chamber and quench areas such as cylinder walls and crevice volumes for all the test fuel blends. It can be perceived that the B20 blend exhibits reduced $\mathrm{HC}$ emission levels at all engine load conditions. The $\mathrm{HC}$ emission trend of the D100 blend is increasing when compared with any other $\mathrm{B} 20$ blend. The $\mathrm{CuO}$ nanoparticle addition in the $\mathrm{B} 20$ blend increases $\mathrm{HC}$ emissions subsequently. The formation of $\mathrm{HC}$ emissions is mainly due to the incomplete combustion, and the concentration of $\mathrm{CuO}$ nanoparticles plays a vital role in the $\mathrm{HC}$ formation inside the combustion chamber. Higher concentration of $\mathrm{CuO}$ nanoparticles tends to be accumulated within the quench layers of the engine cylinder followed by the $\mathrm{HC}$ liberation at subsequent combustion stages. At 100\% load, $\mathrm{HC}$ emissions of the $\mathrm{CuO}$ nanoparticle doped with B20 blend increased by about $0.31 \%, 3.97 \%$, and $9.78 \%$ for B20N25, B20N50, and B20N75 blends, respectively, when compared to the B20 blend. It is obvious that an increase in the concentration of $\mathrm{CuO}$ nanoparticles significantly increases $\mathrm{HC}$ emissions. However, when compared to mineral diesel fuel, $\mathrm{HC}$ emissions were lower for all biodiesel blends at all engine load conditions. Overall, the B20 blend produced the lowest HC emission levels in comparison with other $\mathrm{CuO}$ dosage levels.

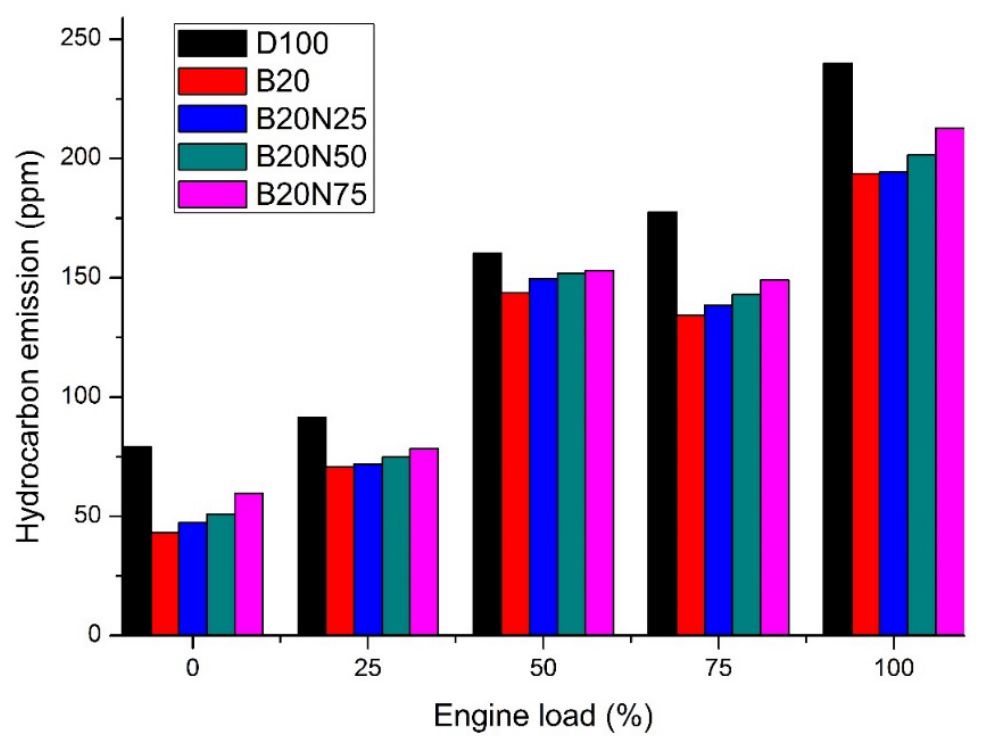

Fig. 8 Hydrocarbon emissions from fuel blends versus engine loads

The influence of $\mathrm{CuO}$ nanoparticles on $\mathrm{NO}_{\mathrm{x}}$ emission levels of the diesel engine for D100, B20, B20N25, B20N50, and B20N75 blends is shown in Fig. 9. It is clear that neat diesel fuel exhibits the lowest $\mathrm{NO}_{\mathrm{x}}$ emission levels in comparison to that of the $\mathrm{B} 20$ blend for all engine loads. The presence of inherent oxygen in the biodiesel blends could have possibly increased the rate of combustion, thus raising the in-cylinder temperature, which is found to be the main cause for $\mathrm{NO}_{\mathrm{x}}$ formation. $\mathrm{NO}_{\mathrm{x}}$ emission levels of the $\mathrm{CuO}$ nanoparticle doped $\mathrm{B} 20$ blend were increased by about $1.75 \%, 3.22 \%$, and $5.27 \%$ for B20N25, B20N50, and B20N75 blends, respectively, when compared to B20. At full engine load condition, the B20N75 blend exhibits the highest emission levels in comparison with those of the B20 blend by about $5.27 \%$. It is due to peak in-cylinder temperatures and the presence of $\mathrm{O}_{2}$ molecules in biodiesel. The presence of $\mathrm{CuO}$ nanoparticles accelerates the oxidation process thereby increasing the incylinder temperature, and $\mathrm{CuO}$ nanoparticles act as a catalyst for the combustion process thereby resulting in increased $\mathrm{NO}_{\mathrm{x}}$ emissions. An increase in $\mathrm{NO}_{\mathrm{x}}$ emission levels for biodiesel blends was also reported in similar studies by Basha and Anand [35]. 
A. Prabhu, M. Venkata Ramanan, Harish Venu, J. Jayaprabakar, M. Anish, Nivin Joy
Emission and Performance Characteristics of a Diesel Engine Using Copper Oxide Nanoparticles in Palm Oil Biodiesel-Diesel Blends

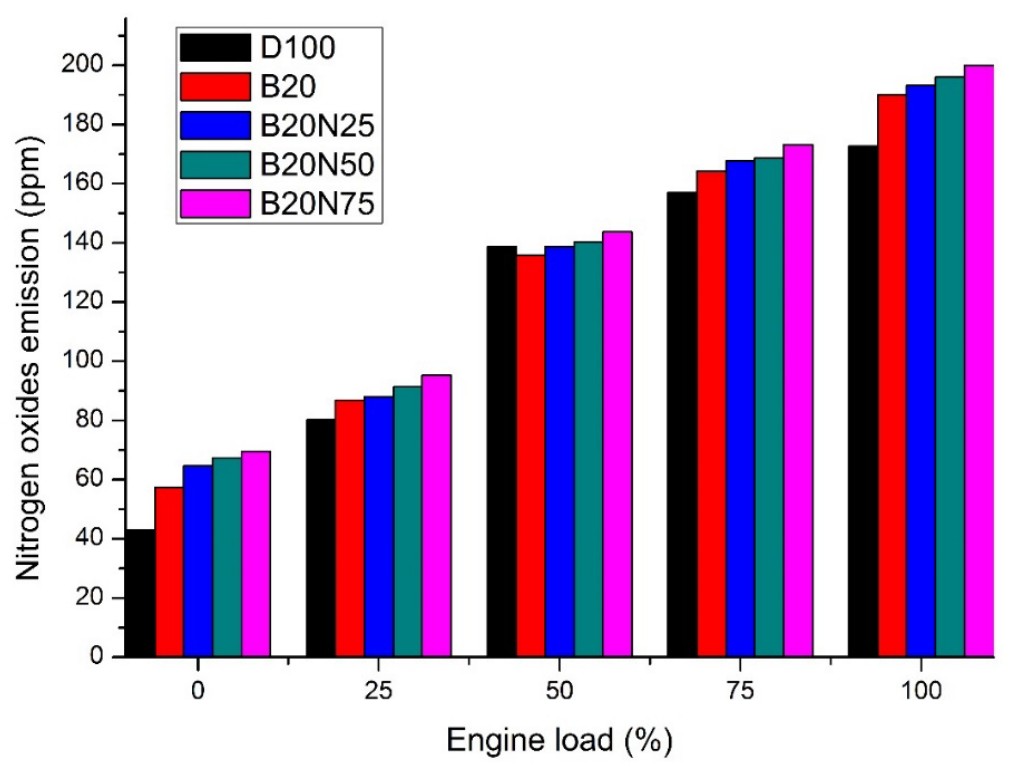

Fig. 9 Nitrogen oxide emissions from fuel blends versus engine loads

The influence of $\mathrm{CuO}$ nanoparticles on the smoke opacity of the diesel engine for D100, B20, B20N25, B20N50, and B20N75 blends is given in Fig. 10. It was found that B20N75 displays the maximum smoke opacity for all engine loads. The smoke opacity of the B20 blend is lower than that of neat diesel by about $20.52 \%$, due to the inherent oxygen content in biodiesel, which promotes the rate of combustion leading to the lowest smoke opacity. In general, smoke occurs because of oxygen deficiency as well as poor atomization, which attributes to the accumulation of fuel in the cylinder. In comparison with mineral diesel, the $\mathrm{CuO}$ nanoparticle doped B20 blend generates considerably reduced smoke emission levels as shown in the Fig. 10. Smoke emissions of the $\mathrm{CuO}$ nanoparticle doped $\mathrm{B} 20$ blend dropped by about $13.24 \%, 7.70 \%$, and $3.05 \%$ for B20N25, B20N50, and B20N75 blends, respectively, when compared to diesel at $100 \%$ engine load condition. The addition of $\mathrm{CuO}$ nanoparticles in B20 results in an improved evaporation rate, reduced ignition delay, and enhanced combustion efficiency. B20N25 showed minimum smoke opacity profile, as a result of the lower viscosity and cetane number which influences the spray and droplet characteristics, which overall reduces the smoke opacity considerably. A similar trend of reduced smoke emission levels with nanoparticles was observed by Basha and Anand [35].

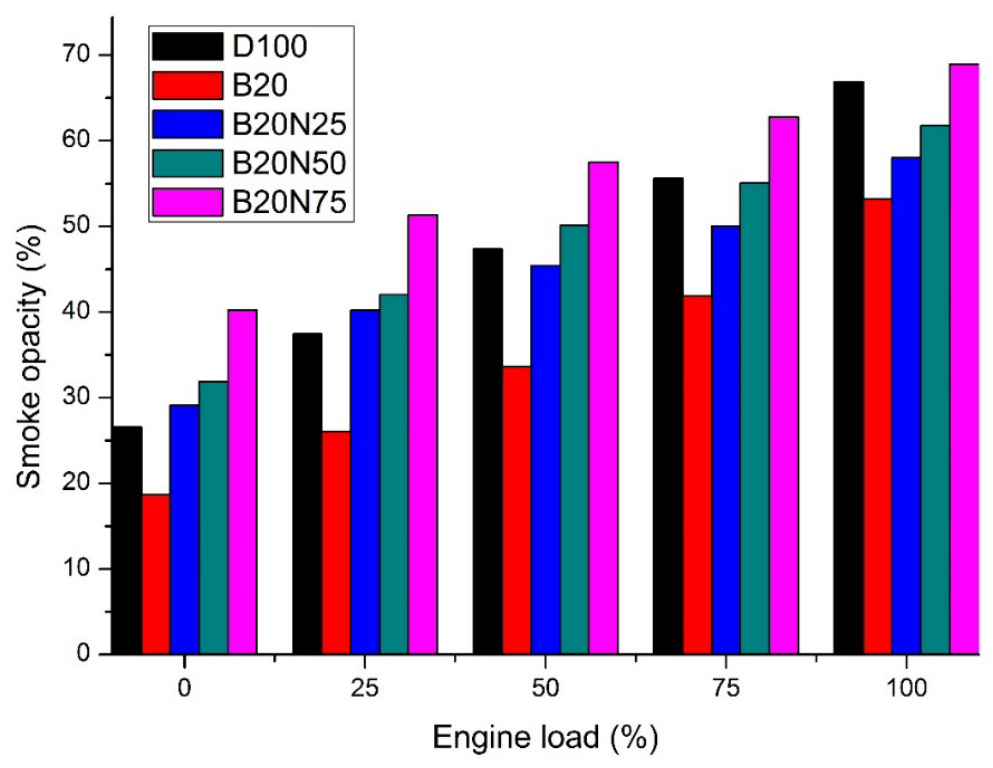

Fig. 10 Smoke opacity for fuel blends versus engine loads 
Emission and Performance Characteristics of a Diesel Engine Using Copper Oxide Nanoparticles in Palm Oil Biodiesel-Diesel Blends
A. Prabhu, M. Venkata Ramanan, Harish Venu, J. Jayaprabakar, M. Anish, Nivin Joy

\section{Conclusions}

The present study deals with the performance and emission characteristics of a single cylinder direct injection diesel engine fuelled by nanoparticle blended biodiesel. The effects of $\mathrm{CuO}$ nanoparticles ( $25 \mathrm{ppm}, 50 \mathrm{ppm}$, and $75 \mathrm{ppm}$ ) added to palm oil biodiesel-diesel blends were experimentally investigated. Based on the experimental results, the following conclusions were drawn:

A substantial improvement in $\mathrm{BTE}$ was achieved by adding $\mathrm{CuO}$ nanoparticles to biodiesel blends. The highest BTE of $30.39 \%$ was achieved for the B20N50 blend, which is $7.6 \%$ lower than that of mineral diesel fuel. The BSEC of $\mathrm{CuO}$ nanoparticle doped biodieseldiesel blends dropped when compared to B20 (the maximum drop of $6.76 \%$ was achieved for B20N50)

As regards emission levels, $\mathrm{CuO}$ nanoparticles addition to the $\mathrm{B} 20$ blend results in a substantial decrease in $\mathrm{CO}$ emission levels $(\mathrm{B} 20 \mathrm{~N} 25>\mathrm{B} 20 \mathrm{~N} 50>\mathrm{B} 20 \mathrm{~N} 75)$ when compared to the B20 blend. However, a substantial increase in $\mathrm{CO}_{2}$ emission levels $(\mathrm{B} 20 \mathrm{~N} 25<\mathrm{B} 20 \mathrm{~N} 50<\mathrm{B} 20 \mathrm{~N} 75)$ is a consequence of a trade-off between $\mathrm{CO}$ and $\mathrm{CO}_{2}$ emissions. In general, $\mathrm{HC}$ and smoke emission levels were lower for biodiesel blends than diesel fuel, but the $\mathrm{HC}$ and smoke emission levels of the $\mathrm{CuO}$ nanoparticle doped $\mathrm{B} 20$ blend increased by about $9.78 \%$ and $7.70 \%$, respectively, for the B20N50 blend when compared to the B20 blend. Higher $\mathrm{NO}_{\mathrm{x}}$ emission levels were found for all biodiesel blends including the $\mathrm{CuO}$ nanoparticle doped biodiesel-diesel blends. The B20N75 blend exhibits higher $\mathrm{NO}_{\mathrm{x}}$ emission levels than the B20 blend by about $5.27 \%$. This could be the only the reason for achieving peak in-cylinder temperatures because of the in-built $\mathrm{O}_{2}$ molecules in the biodiesel structure as well as a nanoparticle.

$\begin{array}{ll}\text { Abbreviations } \\ \text { CuO } & \text { copper oxide } \\ \text { D100 } & \text { neat diesel } \\ \text { B20 } & \text { 20\% palm oil biodiesel }+80 \% \text { diesel } \\ \text { B20N25 } & 20 \% \text { palm oil biodiesel }+80 \% \text { diesel }+25 \text { ppm CuO nanoparticles } \\ \text { B20N50 } & 20 \% \text { palm oil biodiesel }+80 \% \text { diesel }+50 \text { ppm CuO nanoparticles } \\ \text { B20N75 } & 20 \% \text { palm oil biodiesel }+80 \% \text { diesel }+75 \text { ppm CuO nanoparticles } \\ \text { BTE } & \text { brake thermal efficiency } \\ \text { BSFC } & \text { brake specific fuel consumption } \\ \text { BSEC } & \text { brake specific energy consumption } \\ \text { CO2 } & \text { carbon dioxide } \\ \text { CO } & \text { carbon monoxide } \\ \text { HC } & \text { hydrocarbons } \\ \text { NO } & \text { nitrogen oxides } \\ \text { BP } & \text { brake power } \\ \text { EGT } & \text { exhaust gas temperature } \\ \text { TEM } & \text { transmission electron microscope } \\ \text { SEM } & \text { scanning electron microscope } \\ \text { DAS } & \text { data acquisition system }\end{array}$

\section{Funding}

The authors acknowledge that there is no external funding or grants received for this study. 
A. Prabhu, M. Venkata Ramanan, Harish Venu,

J. Jayaprabakar, M. Anish, Nivin Joy
Emission and Performance Characteristics of a Diesel Engine Using Copper Oxide Nanoparticles in Palm Oil Biodiesel-Diesel Blends

\section{Competing interests}

The authors declare no competing financial interest.

\section{Disclosure statement}

No potential conflict of interest was reported by the authors.

\section{REFERENCES}

[1] Venu, H., Raju, V.D. and Subramani, L., 2019. Influence of injection timing on torroidal re-entrant chamber design in a single cylinder DI engine fuelled with ternary blends. Heat and Mass Transfer, pp.1-18. https://doi.org/10.1007/s00231-019-02623-z

[2] Jayaraman, J., Alagu, K., Appavu, P., Joy, N., Jayaram, P. and Mariadoss, A., 2020. Enzymatic production of biodiesel using lipase catalyst and testing of an unmodified compression ignition engine using its blends with diesel. Renewable Energy, 145, pp.399-407. https://doi.org/10.1016/j.renene.2019.06.061

[3] Swamy, D.L.S.V.N., Kowsik, Y., Dhana Raju, V., Appa Rao, K., Venu, H., Subramani, L. and Bala Prasad, K., 2019. Effect of 1-butanol on the characteristics of diesel engine powered with novel tamarind biodiesel for the future sustainable energy source. Energy Sources, Part A: Recovery, Utilization, and Environmental Effects, pp.1-19. https://doi.org/10.1080/15567036.2019.1675810

[4] Venu, H., Raju, V.D., Subramani, L. and Appavu, P., 2019. Experimental assessment on the regulated and unregulated emissions of DI diesel engine fuelled with Chlorella emersonii methyl ester (CEME). Renewable Energy. https://doi.org/10.1016/j.renene.2019.11.010

[5] Sivalingam, A., Kandhasamy, A., Kumar, A.S., Venkatesan, E.P., Subramani, L., Ramalingam, K., Thadhani, J.P.J. and Venu, H., 2019. Citrullus colocynthis-an experimental investigation with enzymatic lipase based methyl esterified biodiesel. Heat and Mass Transfer, pp.1-19. https://doi.org/10.1007/s00231-019-02632-y

[6] Venkatesan, E.P., Kandhasamy, A., Subramani, L., Sivalingam, A. and Kumar, A.S., 2018. Experimental investigation on lemongrass oil water emulsion in low heat rejection direct ignition diesel engine. Journal of Testing and Evaluation, 47(1), pp.238-255. https://doi.org/10.1520/jte20170357

[7] Venu, H. and Appavu, P., 2019. Analysis on a thermal barrier coated (TBC) piston in a single cylinder diesel engine powered by Jatropha biodiesel-diesel blends. SN Applied Sciences, 1(12), p.1669. https://doi.org/10.1007/s42452-019-1771-y

[8] Murugan, N., Venu, H., Jayaraman, J. and Appavu, P., 2019. Emission and performance characteristics study on nanographene oxide additives doped palm oil methyl ester blend in a diesel engine. International Journal of Ambient Energy, (just-accepted), pp.1-27. https://doi.org/10.1080/01430750.2019.1697361

[9] Ma, F. and Hanna, M.A., 1999. Biodiesel production: a review. Bioresource technology, 70(1), pp.1-15.

[10] Iso, M., Chen, B., Eguchi, M., Kudo, T. and Shrestha, S., 2001. Production of biodiesel fuel from triglycerides and alcohol using immobilized lipase. Journal of Molecular Catalysis B: Enzymatic, 16(1), pp.53-58. https://doi.org/10.1016/s1381-1177(01)00045-5

[11] Kusdiana, D. and Saka, S., 2004. Effects of water on biodiesel fuel production by supercritical methanol treatment. Bioresource technology, 91(3), pp.289-295. https://doi.org/10.1016/s0960-8524(03)00201-3

[12] Lingesan, S., Annamalai, K., Parthasarathy, M., Ramalingam, K.M., Dhinesh, B. and Lalvani, J.I.J., 2018. Production of Garcinia gummi-gutta Methyl Ester (GGME) as a potential alternative feedstock for existing unmodified DI diesel engine: combustion, performance, and emission characteristics. Journal of Testing and Evaluation, 46(6), pp.2661-2678. https://doi.org/10.1520/jte20170246

[13] Raju, V.D., Kishore, P.S., Nanthagopal, K. and Ashok, B., 2018. An experimental study on the effect of nanoparticles with novel tamarind seed methyl ester for diesel engine applications. Energy conversion and management, 164, pp.655-666. https://doi.org/10.1016/j.enconman.2018.03.032

[14] Jayaraman, J., Alagu, K., Venu, H., Appavu, P., Joy, N., Jayaram, P. and Mariadhas, A., 2019. Enzymatic production of rice bran biodiesel and testing of its diesel blends in a four-stroke CI engine. Energy Sources, Part A: Recovery, Utilization, and Environmental Effects, pp.1-12. https://doi.org/10.1080/15567036.2019.1671554

[15] Alagu, K., Nagappan, B., Jayaraman, J. and Dhas, A.A.G., 2018. Impact of antioxidant additives on the performance and emission characteristics of CI engine fuelled with B20 blend of rice bran biodiesel. Environmental Science and Pollution Research, 25(18), pp.17634-17644. https://doi.org/10.1007/s11356-018-1934-1 
Emission and Performance Characteristics of a Diesel Engine Using Copper Oxide Nanoparticles in Palm Oil Biodiesel-Diesel Blends
A. Prabhu, M. Venkata Ramanan, Harish Venu, J. Jayaprabakar, M. Anish, Nivin Joy

[16] Fazal, M.A., Sazzad, B.S., Haseeb, A.S.M.A. and Masjuki, H.H., 2016. Inhibition study of additives towards the corrosion of ferrous metal in palm biodiesel. Energy conversion and management, 122, pp.290-297. https://doi.org/10.1016/j.enconman.2016.05.081

[17] Bär, F., Hopf, H., Knorr, M., Schröder, O. and Krahl, J., 2016. Effect of hydrazides as fuel additives for biodiesel and biodiesel blends on NOx formation. Fuel, 180, pp.278-283. https://doi.org/10.1016/j.fuel.2016.04.028

[18] Hosseini, S.H., Taghizadeh-Alisaraei, A., Ghobadian, B. and Abbaszadeh-Mayvan, A., 2017. Performance and emission characteristics of a CI engine fuelled with carbon nanotubes and dieselbiodiesel blends. Renewable energy, 111, pp.201-213. https://doi.org/10.1016/j.renene.2017.04.013

[19] Keskin, A., Gürü, M. and Altıparmak, D., 2008. Influence of tall oil biodiesel with Mg and Mo based fuel additives on diesel engine performance and emission. Bioresource technology, 99(14), pp.6434-6438. https://doi.org/10.1016/j.biortech.2007.11.051

[20] Kumar, M.V., Babu, A.V. and Kumar, P.R., 2018. The impacts on combustion, performance and emissions of biodiesel by using additives in direct injection diesel engine. Alexandria Engineering Journal, 57(1), pp.509-516. https://doi.org/10.1016/j.aej.2016.12.016

[21] Anderson, A., Ramanan, M.V., Prabhu, A. and Jayaprabakar, J., 2019. Influence of nanoparticle with jatropha methyl ester blends in a diesel engine. Digest Journal of Nanomaterials \& Biostructures (DJNB), $14(2)$.

[22] Hosseini, S.H., Taghizadeh-Alisaraei, A., Ghobadian, B. and Abbaszadeh-Mayvan, A., 2017. Effect of added alumina as nano-catalyst to diesel-biodiesel blends on performance and emission characteristics of CI engine. Energy, 124, pp.543-552. https://doi.org/10.1016/j.energy.2017.02.109

[23] Prabu, A. and Anand, R.B., 2016. Emission control strategy by adding alumina and cerium oxide nano particle in biodiesel. Journal of the Energy Institute, 89(3), pp.366-372. https://doi.org/10.1016/j.joei.2015.03.003

[24] Sivakumar, M., Sundaram, N.S. and Thasthagir, M.H.S., 2018. Effect of aluminium oxide nanoparticles blended pongamia methyl ester on performance, combustion and emission characteristics of diesel engine. Renewable energy, 116, pp.518-526. https://doi.org/10.1016/j.renene.2017.10.002

[25] Ganesh, D. and Gowrishankar, G., 2011, September. Effect of nano-fuel additive on emission reduction in a biodiesel fuelled CI engine. In 2011 International conference on electrical and control engineering (pp. 3453-3459). IEEE. https://doi.org/10.1109/iceceng.2011.6058240

[26] Mehta, R.N., Chakraborty, M. and Parikh, P.A., 2014. Nanofuels: Combustion, engine performance and emissions. Fuel, 120, pp.91-97. https://doi.org/10.1016/j.fuel.2013.12.008

[27] Hosseini, S.H., Taghizadeh-Alisaraei, A., Ghobadian, B. and Abbaszadeh-Mayvan, A., 2017. Performance and emission characteristics of a CI engine fuelled with carbon nanotubes and dieselbiodiesel blends. Renewable energy, 111, pp.201-213. https://doi.org/10.1016/j.renene.2017.04.013

[28] Choi, H.L., Sudiarto, S.I. and Renggaman, A., 2014. Prediction of livestock manure and mixture higher heating value based on fundamental analysis. Fuel, 116, pp.772-780. https://doi.org/10.1016/j.fuel.2013.08.064

[29] Gumus, S., Ozcan, H., Ozbey, M. and Topaloglu, B., 2016. Aluminum oxide and copper oxide nanodiesel fuel properties and usage in a compression ignition engine. Fuel, 163, pp.80-87. https://doi.org/10.1016/j.fuel.2015.09.048

[30] Bragadeshwaran, A., Kasianantham, N., Ballusamy, S., Tarun, K.R., Dharmaraj, A.P. and Kaisan, M.U., 2018. Experimental study of methyl tert-butyl ether as an oxygenated additive in diesel and Calophyllum inophyllum methyl ester blended fuel in CI engine. Environmental Science and Pollution Research, 25(33), pp.33573-33590. https://doi.org/10.1007/s11356-018-3318-y

[31] Raju, V.D., Kishore, P.S., Nanthagopal, K. and Ashok, B., 2018. An experimental study on the effect of nanoparticles with novel tamarind seed methyl ester for diesel engine applications. Energy conversion and management, 164, pp.655-666. https://doi.org/10.1016/j.enconman.2018.03.032

[32] Tyagi, H., Phelan, P.E., Prasher, R., Peck, R., Lee, T., Pacheco, J.R. and Arentzen, P., 2008. Increased hot-plate ignition probability for nanoparticle-laden diesel fuel. Nano letters, 8(5), pp.1410-1416. https://doi.org/10.1021/n1080277d

[33] Patel, H.K. and Kumar, S., 2017. Experimental analysis on performance of diesel engine using mixture of diesel and bio-diesel as a working fuel with aluminum oxide nanoparticle additive. Thermal Science and Engineering Progress, 4, pp.252-258. https://doi.org/10.1016/j.tsep.2017.09.011 
A. Prabhu, M. Venkata Ramanan, Harish Venu, J. Jayaprabakar, M. Anish, Nivin Joy
Emission and Performance Characteristics of a Diesel Engine Using Copper Oxide Nanoparticles in Palm Oil Biodiesel-Diesel Blends

[34] Kannan, G.R., Karvembu, R. and Anand, R., 2011. Effect of metal based additive on performance emission and combustion characteristics of diesel engine fuelled with biodiesel. Applied energy, 88(11), pp.3694-3703. https://doi.org/10.1016/j.apenergy.2011.04.043

[35] Basha, J.S. and Anand, R.B., 2011. An experimental study in a CI engine using nanoadditive blended water-diesel emulsion fuel. International journal of green energy, 8(3), pp.332-348. https://doi.org/10.1080/15435075.2011.557844

Submitted: $\quad 29.12 .2019$

Accepted: $\quad 18.02 .2021$

\author{
A.Prabhu, Research scholar,* \\ M.Venkata Ramanan, Professor, \\ Department of Mechanical Engineering, \\ College of Engineering, Guindy, \\ Anna University, Chennai, India \\ Harish Venu, Assistant Professor, \\ Department of Automobile Engineering, \\ Vel Tech Rangarajan Dr.Sagunthala R\&D \\ Institute of Science and Technology, \\ Chennai, India \\ J.Jayaprabakar, Associate Professor, \\ M.Anish, Assistant Professor \\ Nivin Joy, Assistant Professor \\ School of Mechanical Engineering, \\ Sathyabama Institute of Science and \\ Technology, Chennai, India \\ Corresponding author: \\ *prabhuappavu@gmail.com
}

